\title{
The Use of Mind Mapping Strategy in Malaysian University English Test (MUET) Writing
}

\author{
Melor Md Yunus, Chan Hua Chien \\ Faculty of Education, Universiti Kebangsaan Malaysia, Bangi, Malaysia \\ Email: melor@ukm.edu.my, huachien87@hotmail.my
}

Received 28 February 2016; accepted 12 April 2016; published 15 April 2016

Copyright (C) 2016 by authors and Scientific Research Publishing Inc.

This work is licensed under the Creative Commons Attribution International License (CC BY).

http://creativecommons.org/licenses/by/4.0/

(c) (i) Open Access

\section{Abstract}

This study aims to investigate SMK Oya Pre-U students' perceptions on the use of mind mapping strategy in their MUET (Malaysian University English test) writing. To achieve the aim of the study, a questionnaire was used to collect both quantitative and qualitative data. Therefore, 25 SMK Oya Pre-U students with different band achievement in MUET (Malaysian University English Test) were selected to participate in this study. The analysis of the data indicated that majority of the students had positive perceptions of the use of mind mapping strategy in enhancing their writing skills. The use of mind mapping helps students in planning their writing, adapting a deeper level of understanding of the writing topics and promoting creativity in writing. The findings of the study are hoped to provide insights to the students, teachers and curriculum designers to integrate mind mapping strategy in ESL (English as a Second Language) writing classes. Instructional implications are provided as well.

\section{Keywords}

Mind Mapping, Perceptions, Writing, Writing Tool, English as a Second Language

\section{Introduction}

Writing has been widely regarded as a crucially essential skill in the teaching and learning of English as a Second Language (ESL) as it is a comprehensive skill that helps reinforce vocabulary, grammar, thinking, planning, editing, revising, and other elements. Writing also helps to improve all the other skills of listening, speaking and reading as they are all interrelated (Saed \& Al-Omari, 2014). Writing does not only stimulate thinking, compel students to concentrate and organize their ideas, and cultivate their abilities to summarize, analyze, and 
criticize. At the same time, it also emphasizes constant learning in, thinking in, and doing reflection in the English language (Maghsoudi \& Haririan, 2013). Hence, in Malaysia, English writing skill is a skill that not only is tested in every valid language examination at different levels of education, but also a skill that learners should possess and demonstrate in academic contexts. This is clearly seen in MUET (Malaysian University English Test) where writing sections have significantly large weighting (30\%) of the examination total score after reading section which contributes $40 \%$ of the overall mark. Candidates are assessed on their ability to construct different written texts with various rhetorical styles which include accuracy, appropriacy, coherence and cohesion (ideas development and organization), use of language functions for different purposes and lastly task fulfillment which would assess students' ability and mature treatment on topic by providing adequately relevant content. All Pre-U students are compulsory to take MUET as it is a prerequisite for applying for admissions to all public universities and colleges in Malaysia.

Nevertheless, students find composing in English difficult because the writing process demands them to employ many cognitive and linguistic strategies of which they are uncertain (Maghsoudi \& Haririan, 2013). Even when they write, they look worried, hesitant, and thus their written points are disorganized. They may have some ideas for writing, but they are usually unable to convey and transform them into writing using proper language, diction, and cohesion. According to Firmansyah (2015), the major problems faced by students in writing are their inadequacy of ability to generate ideas; therefore, they are lacking ideas what to write first. Secondly, the students had difficulty in making the paragraphs with the topic. Also, the students had difficulty in choosing the word due to lack of vocabulary. The researcher thinks that this could be due to the teaching strategies used by the teachers, the types of feedback students receive from books and instructors, the types of writing activities carried out in classrooms, or lack of opportunities to practice writing.

At the same time, teachers also find that writing is the hardest skill to be taught compared to other language skills such as speaking, listening and reading as writing skills are hard to measure (Akinwamide, 2012). Alsamadani (2010, p. 53 cited in Javid \& Umer, 2014) also stated that writing "is a complex, challenging, and difficult process" because it includes multiple skills such as generating thesis statement, writing supporting details and elaborating the topic sentences, reviewing for mistakes made and making necessary editing after reviewing. This complex process makes writing the hardest skill to be taught. In addition, writing also requires adequately comprehensive knowledge of grammar, appropriate choice of words or phrases, writing mechanics, organizational skills and style of writing. Another factor that makes the teaching of writing rather difficult is that writing is significantly related other language skills.

The mind mapping strategy is one of the effective strategies in teaching writing. A mind map is considered a diagram used to represent the relationship of words, ideas, tasks, or other items connected to and arranged around a central key word or idea (Deshatty \& Mokashi, 2013). It is thus an effective tool to aid in studying and organizing information as well as writing. It helps students to associate ideas, promote creative thinking, and establish meaningful connections among ideas (Buzan, 2010). The Ministry of Education Malaysia and Agensi Inovasi Malaysia (AIM) have also introduced i-Think programme which promotes critical, analytical and creative thinking in the learning process by using eight thinking maps (circle map, bubble map, double bubble map, tree map, flow map, multi-flow map, brace map, and bridge map) that could be applied in virtually any lesson as an initiative to transform the culture of current education and enhance the teachers' capacity.

The focus of this study is limited to examining the perceptions of SMK Oya Pre-U (Form 6) students toward the use of mind mapping technique in writing. In this research, the researcher states the hypothesis as follows: There is a significant influence of mind mapping technique on students' ability in MUET writing. Therefore, this study aims to investigate and explore the students' perceptions of using mind mapping strategy in MUET writing class. In order to facilitate the investigation regarding the use of mind mapping technique in writing argumentative text, the following research questions were formulated: 1) What are SMK Oya Pre-U students' perceptions on the use of mind mapping strategy in promoting their writing skills? 2) What are the benefits of using mind mapping strategy in writing? and 3) How does mind mapping strategy help them in writing?

\section{Literature Review}

\subsection{Writing Skills}

Writing can be considered a necessity in a larger context of life beyond the classroom, not just another section that will come up in the context of a standardized national examination. Riswanto and Putra (2012) stated that 
writing is one of the language skills that will never become obsolete in education. It is not only essentially important in language class, but also in other classes of other subjects. Ahangari and Behzady (2011) mentioned that writing is one of the best ways to keep track of learning. Writing is also one of the most difficult skills for the students to acquire as writing requires a number of skills and conventions like organizing and developing ideas and information, choosing the right vocabulary accurately to eradicate the ambiguity of meaning and also the practice of accurate grammatical devices to focus and emphasize ideas (Nik et al., 2010, Yunus et al., 2013). Furthermore, writing demands the writer to choose the choice of vocabulary carefully and have a comprehensive knowledge of grammatical patterns in order to be able to write sentence structures that are pertinent to the subject matter (Ali \&Yunus, 2004). Therefore, ESL students should have frequent practice on writing other than having knowledge of skills and conventions of writing.

\subsection{Mind-Mapping Strategy}

Mind mapping, which is popularized by Tony Buzan, is an effective diagram with the function of organizing ideas and representing words, ideas, or another links that arranged a central point by branches and contains words, phrases colors, and visual images (Buzan, 2006). Mind mapping involves writing down a central idea and coming out with new and related ideas from the centre. The mind mapping strategy can be used to explore a wide range of topics in writing and also used in every kind of writing such as: narrative, descriptive, recount, persuasive and argumentative (Riswanto \& Prandika, 2012). Students can improve their ideas as mind maps work well as an effective visual design that enables students to clearly see the relationship between ideas, and consequently encourages them to group certain ideas together according to their similar characteristics as they proceed (Padang \& Gurning, 2014). By mind mapping, one can develop their ability in memorizing, brainstorming, learning, as well as creativity (Ingemann, 2008 as cited in San Risqiya, 2013). A study done by Padang \& Gurning (2014) on improving students' achievement in constructing descriptive written text through mind mapping strategy which was conducted among 30 students of class VIII SMP Swasta HKBP Pardamean showed that Mind Mapping Strategy could improve the students' achievement in writing and also help the teacher in their lessons of teaching writing. This improvement not only resulted in the increment of the mean of the students' score, but also greatly enhancing the students' enthusiasm, motivation and expression in writing.

Another study done by Saed \& AL-Omari (2014) on the effectiveness of a proposed program based on a mind mapping strategy in developing the writing achievement of eleventh grade EFL students in Jordan which involved 91 female students of the first semester of the academic year 2013/2014 at Sands National Academy, Amman Second Directorate of Education has shown that students who used mind mapping strategy to organize and summarize information in their draft of writing produced more transformations of ideas in their summaries than the students who did not use this strategy. Mind mapping gives students the opportunity to solidify their ideas before writing. The students' ability to transfer meaning to write summaries improved significantly; they were able to write more complete and well-organized summaries.

Warsidi, Arafah \& Makka (2014) also found out in their study that the students' writing ability can be improved through the collaboration of mind mapping and organizational pattern. The improving items in writing were contents, organizations, vocabularies and language use. Hence, the use of collaboration of mind mapping and organizational pattern builds the students' positive attitudes because it can motivate and help them to write an essay. According to Budd (2004) as cited in Jones et al. (2012), mind maps allow students to create a visual image to enhance their learning thus it can be used as a metacognitive tool that allows them to establish meaningful connections between various ideas.

According to Naqbi (2011) in her study on "The Use of Mind Mapping to Develop Writing Skills in UAE Schools" which used a classroom-based action research to retrieve data from a group of female Grade 11, English as a Foreign Language (EFL) learners between sixteen and seventeen years old in the school of United Arab Emirates (UAE), mind mapping strategy is s a powerful tool to help students in organizing and developing their ideas and thoughts. Moreover, mind mapping technique is also an effective tool to develop students' cognition skills and help them in doing assessment or reflection. The students' skills at generating ideas and evaluating them quickly are enhanced. They were able to recall and retrieve their prior knowledge about different topics which is beneficial for designing mind maps. Therefore, it could be said that mind mapping can have a positive impact on students' cognition skills and information retrieval skills. The researcher concluded her study by saying that the mind mapping technique is an appropriate tool to help students in planning their writing as the ap- 
proach encourages students to gain an in-depth understanding of the writing topics (Naqbi, 2011).

Jones et al. (2012) revealed in their study on "The Effects of Mind Mapping Activities on Students' Motivation" which conducted among 40 undergraduate students who studied in an educational psychology course at a U.S. university that mind mapping activities were empowering, useful and motivating to students. Students perceived mind mapping as an entertaining and interesting approach which would greatly enhance their learning as well. Some students preferred individual mind mapping while some preferred group mind mapping. The researchers concluded their study by suggesting that instructors should give the students freedom to choose their favourite mapping activity options. By allowing students to choose whether to complete the map on their own or with a group in class or out of class would lead to greater engagement as the students are taking charge of their own learning.

\section{Methodology}

This part mainly deals with the methodology used in this study, which consists of two sections namely the research design and research instrument

\subsection{Research Design}

This study employed a survey in which the researcher simultaneously collected both quantitative and qualitative data using to measure the perception of students on the effectiveness of using mind mapping strategy in writing argumentative text. The respondents of the questionnaire consisted of 25 Pre-U (Form 6) students in SMK Oya, Dalat who are taking MUET subject. The background of these students ranged from very limited users to satisfactory users in their MUET achievement. The participants ranged from 18 to 19 years of age.

\subsection{Research Instrument}

The questionnaire items were adapted from Goodnough \& Woods' (2002) study. The questionnaire was made up of two sections: 1) seven close-ended items and 2) two open-ended items. The seven close-ended questions were designed to elicit the students' perceptions toward the use of mind mapping strategy in MUET writing. Moreover, two open-ended questions were designed to allow students the freedom to give their views on the advantages of using mind mapping strategy in writing and how this strategy helps them in writing. In the analysis phase of the study, the percentages for each close-ended item were calculated and the results were presented in the tables. Moreover, the responses to the open-ended items were categorized, coded and analyzed based upon the extracted themes.

\section{Results and Discussion}

The findings are presented in three sections. Each section discusses the objectives of this research namely SMK Oya Pre-U students' perceptions of using mind mapping technique in their writing, benefits of using mind mapping technique, as well as how mind mapping technique helps them in MUET writing.

\subsection{Demographic Data}

There are 22 female (88\%) and 3 male (12\%) respondents who responded to the questionnaire. All the respondents are in the age group of 18-19 years. The gender figures are almost representative of the ratio of the general population of Pre-U students in SMK Oya. In terms of their language proficiency, all respondents' MUET band is between 2 and 4. Bands 2, 3 and 4 constitute "Limited User", "Modest User" and "Competent User" respectively. Therefore, all respondents have good command of the English Language, with 15 (60\%) of them in Band 2, 8 (32\%) in Band 3 while another 2 (8.0\%) in Band 4

\subsection{Students' Perceptions on the Use of Mind Mapping Strategy in Writing}

The answers to the questionnaire were based on the Likert scales, these answers are showed in Table 1.

As noted by the responses presented in Table 1, SMK Oya Pre-U students generally have positive responses to the use of mind mapping strategy in writing. More than half of the students (56\%) disagreed that creating mind map is a difficult task (item 1) and $64 \%$ of them actually enjoy creating mind maps (item 3 ). This is sup- 
Table 1. Students' responses to the use of mind mapping strategy in writing.

\begin{tabular}{|c|c|c|c|c|c|c|c|c|c|c|}
\hline \multirow{3}{*}{ Items } & \multicolumn{10}{|c|}{ Students' Responses } \\
\hline & \multicolumn{2}{|c|}{$\begin{array}{c}1 \\
\text { Strongly Agree }\end{array}$} & \multicolumn{2}{|c|}{$\begin{array}{c}2 \\
\text { Agree }\end{array}$} & \multicolumn{2}{|c|}{$\begin{array}{c}3 \\
\text { Disagree }\end{array}$} & \multicolumn{2}{|c|}{$\begin{array}{c}4 \\
\text { Strongly Disagree }\end{array}$} & \multicolumn{2}{|c|}{$\begin{array}{c}5 \\
\text { Not Certain }\end{array}$} \\
\hline & $\mathrm{F}$ & $\%$ & $\mathrm{~F}$ & $\%$ & $\mathrm{~F}$ & $\%$ & $\mathrm{~F}$ & $\%$ & $\mathrm{~F}$ & $\%$ \\
\hline 1 & 0 & $0 \%$ & 8 & $32 \%$ & 13 & $52 \%$ & 1 & $4 \%$ & 3 & $12 \%$ \\
\hline 2 & 1 & $4 \%$ & 21 & $84 \%$ & 1 & $4 \%$ & 0 & $0 \%$ & 2 & $8 \%$ \\
\hline 3 & 3 & $12 \%$ & 13 & $52 \%$ & 8 & $32 \%$ & 0 & $0 \%$ & 1 & $4 \%$ \\
\hline 4 & 0 & $0 \%$ & 3 & $12 \%$ & 19 & $76 \%$ & 1 & $4 \%$ & 2 & $8 \%$ \\
\hline 5 & 2 & $8 \%$ & 19 & $76 \%$ & 1 & $4 \%$ & 0 & $0 \%$ & 3 & $12 \%$ \\
\hline 6 & 5 & $20 \%$ & 16 & $64 \%$ & 2 & $8 \%$ & 0 & $0 \%$ & 2 & $8 \%$ \\
\hline 7 & 5 & $20 \%$ & 18 & $72 \%$ & 1 & $4 \%$ & 0 & $0 \%$ & 1 & $4 \%$ \\
\hline
\end{tabular}

ported by Jones et al. (2012) who claimed in their study that mind mapping is an entertaining and interesting approach enhanced students' learning. 32\% of them dislike creating mind maps as they perceive it as a time consuming and difficult task. They have probably never used mind map in their pre-writing process, and thus they are lacking necessary skills and find it hard to create a mind map before moving on to their actual writing. Moreover, an average number of students (80\%) disagreed that creating a class mind map was a boring experience (item 4). Only $12 \%$ of them perceived creating class mind map as a mundane task. This was probably because they are lacking of skills to come out with a comprehensive and well-organized mind maps which work well as a visual design and hence they perceived it as a mundane task.

When looking at student's perception of the usefulness of mind mapping in organizing thoughts, the responses presented in Table 1 suggest that, majority of the students (88\%) agreed that mind mapping helped them organize their thoughts (item 2) with $4 \%$ of them disregard mind mapping as a useful tool in organizing their thoughts. Students overall (84\%) perceived that mind mapping was a valuable strategy for helping them in understanding concepts and ideas (item 5) and allowing them to be creative (item 6). This is supported by Naqbi (2014) who claimed that mind mapping may impact on students' abilities to plan and organize their ideas for writing tasks and aid in developing students' cognition skills as well as information recovery. A minority of them (4\% to $12 \%$ ) was unsure about the usefulness of mind map as a learning tool in helping them to organize thoughts, understand concepts and ideas, and be creative. They were unsure most probably due to the reason that they have never integrated mind map in their writing before and hence they are not aware of the usefulness of mind map in writing. Nearly all of them (92\%) with $20 \%$ of them strongly agreed that mind mapping strategy helped them to understand the relationship between ideas they wrote and the writing topic (item 7). Hence, they would subsequently show more coherence in their writing. This is in alignment with Saed \& AL-Omari (2014) who claimed that mind mapping gives students the opportunity to solidify their ideas with adequate ideas before they move on to writing.

\subsection{Benefits of Using Mind Mapping}

When reviewing students' responses to the open-ended questions, there are lots of purposes and advantages of using mind mapping strategy in writing. Most of the students stated that mind mapping technique contributes to helping their writing ability in writing and make their writing easier. As mind mapping helps them to organize their ideas effectively, understand the topic and their written information easily and thus able to relate them effectively, and develop or elaborate ideas more effectively. This is found in students' responses:

- Mind mapping can help me to organize ideas and understand my written information easily

- It (mind mapping) helps me to develop ideas more effectively and at the same time it makes our writing easier

- I can understand more on my topic of the essay and I can elaborate more on the topic

Keles (2012) also claimed that mind mapping can assist learning by providing an opportunity for visual sti- 
muli, assessment, checking understanding, elaboration, note taking, summarizing, illustrating sequence of events, and other creative ways of instruction. Moreover, mind mapping also helps to promote their creativity in writing. This is found in few of the responses given by the students:

- It (mind mapping) helps me to be more creative in my writing; this is because I need to think wisely to relate the main idea with its elaboration.

- It (mind mapping strategy) can promote our creativity by using mind mapping strategy in our writing

This has supported Keles (2012) who claimed that mind maps are effective tools in learning and promoting students' creative and critical thinking and in providing permanent learning.

\subsection{The Use of Mind Mapping Strategy in Writing MUET Essays}

Most of the students (92\%) generally have positive responses to the use of mind mapping strategy in their MUET writing and they claimed that mind mapping does help them in writing. Below are their responses to the question on how the use of mind mapping helps them in writing.

- It (mind mapping strategy) helps me to organize ideas before I move on writing.

- Because I can save time to not writing too much

- It (mind mapping strategy) also helps me to create more ideas in my writing as I can give many examples based on it.

- Mind mapping allows me to list my points and I can easily elaborate on my points

- I also can develop ideas more easily.

- Because it (mind mapping strategy) helps me to be more creative and I also can write my points that are related to the topic

To sum up, mind mapping has beneficial effects on students' writing. Bharambe (2012) also claimed that mind mapping provides a useful focus for students to organize their thoughts and ideas to present information clearly and attractively. On the other hand, 2 of the students (8\%) stated that mind mapping does not help them in writing as they are lacking of skills in creating a comprehensive mind map and thus they find it mundane and difficult;

- I didn’t understand my own mind map sometime. For me, the colourful mind map is so irritating and boring. I prefer to make simple note but in different colorful paper.

- I do not really understand what I had created actually.

It is noted that even mind mapping is good for teaching learning, but it has disadvantages too. According to Muhib, Anggani \& Hartono (2014), the disadvantages of Mind Mapping is that it demands a great amount of time in organization and finding an effective keyword and thus, it is sometimes difficult for students to create a comprehensive mind map due to the allocation of time needed.

\section{Conclusion and Implications}

Based on the research findings and discussion above, it can be generally depicted that most of the SMK Oya Pre-U students perceive mind mapping technique as an effective strategy in helping them to write and this is in agreement with those seen from previous research which demonstrated that mind mapping technique can enhance the students' writing ability. As a result, the mind mapping technique would seem to be an effective tool to help students in planning and organizing their writing by encouraging students to gain a comprehensive or in-depth understanding of the writing topics. In contrast, a minority of them claimed that creating mind mapping is difficult, boring and time-consuming and does not benefit their writing and thus they dislike creating mind maps. This could be true when using this strategy in an exam situation where students are having difficulties to familiarize themselves with the concept of the mind mapping strategy in such conditions. Students who have insufficient skills to draw need a long time to make a mind mapping as they usually focused more only to make an effective mind map with good visual aids without estimated time to make a good writing product. Nevertheless, this weakness can be solved by the teachers giving clear instructions to clear the students' doubts and limited time frame for the students to create mind maps more efficiently.

Although the aims of the study have been achieved, there are certain inevitable limitations. Due to the time limitation, only a small size of population was involved in this study. This study should be extended to involve more Pre-U students from different schools in order to make generalization over larger groups. Secondly, only students' perceptions of the use of mind mapping strategy in their writing were explored in this study. A detailed study which aims to explore the effectiveness of employing mind mapping strategy in students' MUET writing 
should be carried out in order to investigate whether the students’ positive responses towards current study are in alignment with their scores in writing after employing mind mapping strategy in their writing.

The paper has some beneficial implications for language teaching and learning. Students are encouraged to use mind mapping strategy at their pre-writing phase which helps to organize their thoughts and broaden their writing skills. Teachers should emphasize mind mapping as a teaching technique at the prewriting phase with the aim of motivating students and activating their prior knowledge which is useful for generating ideas. Likewise, the paper has some implications for syllabus design. Curriculum developers and textbook writers may incorporate teaching strategies that can help students write using the mind mapping techniques or steps to help them develop as creative writers. Although the present study suggests that the strategy of mind mapping is beneficial to Pre-U students, there are areas that need to be studied further. One area for doing more research is to conduct such studies with a variety of language students with different educational backgrounds. Another area that could be studied further is the effect of mind mapping on developing other language skills among students at different levels.

\section{References}

Ahangari, S., \& Behzady, L. (2011). The Effect of Explicit Teaching of Concept Maps on Iranian EFL.

Akinwamide, T. K. (2012). The Influence of Process Approach on English as Second Language Students' Performances in Essay Writing. ELT, 5, 16-29.

Ali, Z., \& Yunus, M. M. (2004). An ESL Writing Course: Unravelling Students' Needs and Concerns. The English Educator, XXXII, 114. http://www.melta.org.my

Alsamadani, H. A. (2010). The Relationship between Saudi EFL Students' Writing Competence, L1 Writing Proficiency, and Self-regulation. European Journal of Social Sciences, 16, 53-63.

Bharambe, M. I. (2012). Effectiveness of Mind Mapping in Educational Psychology. Journal of Biological Chemistry, 2, $10-18$.

Buzan, T. (2006). Learning Skills: Mind Mapping: Mind Mapping, Whole Brain Note Taking, Uses Both Sides of Your Brain to Study Subjects Usually Only Studies with Your Left Brain. http://digilib.unnes.ac.id

Buzan, T. (2010). Buku Pintar Mind Mapping Untuk Anak. Jakarta: PT Gramedia Pustaka Utama

Deshatty, D. D., \& Mokashi, V. (2013). Mind Maps as a Learning Tool in Anatomy. International Journal of Anatomy and Research, 1, 100-103.

Firmansyah, A. (2015). The Influence of Mind Mapping Technique and Students’ Attitude toward Students’ Ability in Writing a Recount Text of the Eighth Grade Students of State Junior High School 45 Palembang. RIPTEKSI KEPENDIDIKAN PGRI.

Goodnough, K., \& Woods, R. (2002). Student and Teacher Perceptions of Mind Mapping: A Middle School Case Study.

Javid, C., \& Umer, M. (2014). Saudi EFL Learners' Writing Problems: A Move towards Solution. Proceeding of the Global Summit on Education GSE, 4-5.

Jones, B. D., Ruff, C., Snyder, J. D., Petrich, B., \& Koonce, C. (2012). The Effects of Mind Mapping Activities on Students' Motivation. International Journal for the Scholarship of Teaching and Learning, 6, 1-21.

http://dx.doi.org/10.20429/ijsotl.2012.060105

Keleş, Ö. (2012). Elementary Teachers' Views on Mind Mapping. International Journal of Education, 4, 93. http://dx.doi.org/10.5296/ije.v4i1.1327

Maghsoudi, M., \& Haririan, J. (2013). The Impact of Brainstorming Strategies Iranian EFL Learners Writing Skill Regarding Their Social Class Status. Journal of language and linguistics, 1, 60-67. http://dx.doi.org/10.11648/j.ijll.s.20130101.20

Muhib, A., Anggani LB, D., \& Hartono, R. (2014). Mind Mapping and Everybody Writes Techniques for Students with High and Low Writing Achievement. English Education Journal, 4, 99-105.

Naqbi, S. A. (2011). The use of Mind Mapping to Develop Writing Skills in UAE Schools. Education, Business and Society: Contemporary Middle Eastern Issues, 4, 120-133. http://dx.doi.org/10.1108/17537981111143855

Nik, Y. A., Hamzah, A., \&Rafidee, H. (2010). A Comparative Study on the Factors Affecting the Writing Performance among Bachelor Students. International Journal of Educational Research and Technology, 1, 54-59.

Padang, J. S. M., \& Gurning, B. (2014). Improving Students’ Achievement in Writing Descriptive Text through Mind Mapping Strategy. Register Journal of English Language Teaching of FBS-Unimed, 3, 1-11.

Riswanto, \& Prandika, P. P. (2012). The Use of Mind Mapping Strategy in the Teaching of Writing at SMAN 3 Bengkulu, Indonesia. International Journal of Humanities and Social Science, 2, 60-68. 
Saed, H. A., \& AL-Omari, H. A. (2014). The Effectiveness of a Proposed Program Based on a Mind Mapping Strategy in Developing the Writing Achievement of Eleventh Grade EFL Students in Jordan and Their Attitudes Towards Writing. Journal of Education and Practice, 5, 88-109.

San Risqiya, R. (2013). The Use of Mind Mapping in Teaching Reading Comprehension. ELTIN Journal, 1, 32-43.

Yunus, M. M., Nordin, N., Salehi, H., Embi, M. A., \& Salehi, Z. (2013). The Use of Information and Communication Technology (ICT) in Teaching ESL Writing Skills. English Language Teaching, 6, 1-8. http://dx.doi.org/10.5539/elt.v6n7p1

\section{Appendix}

Sex: Male ( ) Female $(\quad)$ Muet Band: $1(\quad) \quad 2(\quad) \quad 3(\quad) \quad 4(\quad) \quad 5(\quad) \quad 6(\quad)$

Age: $18(\quad) \quad 19(\quad)$

Part A: Please read each of the following statements about mind mapping carefully. Circle the answer that best reflects how you feel about the statement.

1. It is difficult to create map.
(A) Strongly Agree
(B) Agree
(C) Disagree
(D) Strongly Disagree
(E) Not Certain

2. Mind maps help me organize my thoughts.
(A) Strongly Agree
(B) Agree
(C) Disagree
(D) Strongly Disagree
(E) Not Certain

3. I enjoy creating mind maps.
(A) Strongly Agree
(B) Agree
(C) Disagree
(D) Strongly Disagree
(E) Not Certain

4. Creating a class mind map was a boring experience.
(A) Strongly Agree
(B) Agree
(C) Disagree
(D) Strongly Disagree
(E) Not Certain

5. Mind mapping helps me understand concepts and ideas.
(A) Strongly Agree
(B) Agree
(C) Disagree
(D) Strongly Disagree
(E) Not Certain
6. Mind mapping allows me to be creative.
(A) Strongly Agree
(B) Agree
(C) Disagree
(D) Strongly Disagree
(E) Not Certain

7. Creation of a class mind map helped me understand the relationship between the ideas I wrote and the topic.
(A) Strongly Agree
(B) Agree
(C) Disagree
(D) Strongly Disagree
(E) Not Certain

Part B: Please read each question carefully. Write your response in the space provided after each item.

1. What are the purposes and advantages of using mind mapping strategy in your writing?

2. Did the use of mind mapping help you in writing MUET argumentative essays? How? Explain your answer. 